\title{
Infiltration of Mould from Crawl Space under the Prefabricated Bathroom
}

\author{
Motoya Hayashi'1, Haruki Osawa' $^{2}$, Kenichi Hasegawa ${ }^{3}$, Yoshinori Honma4, Hiromi Yamada5 \\ ${ }^{1}$ Department of Life Style and Space Design, Miyagigakuin Women's University, Sendai, Japan \\ ${ }^{2}$ National Institute of Public Health, Wakou, Japan \\ ${ }^{3}$ Akita Prefectural University al Institute, Yurihonjo, Japan \\ ${ }^{4}$ Iwate Prefectural University al Institute, Morioka, Japan \\ ${ }^{5}$ Matsue College of Technology, Matsue, Japan \\ Email: mhns01234@aol.com
}

Received 13 May 2014; revised 8 June 2014; accepted 1 July 2014

Copyright (C) 2014 by authors and Scientific Research Publishing Inc.

This work is licensed under the Creative Commons Attribution International License (CC BY). http://creativecommons.org/licenses/by/4.0/

(c) (i) Open Access

\begin{abstract}
The indoor mould concentration depends not only on the outdoor mould source but also on the indoor mould source. The mould source is not only on the interior surface but also in the concealed spaces: a crawl space, a beam space, a wall cavity etc. Most detached houses in Japan have crawl spaces under the first floor. The humidity is high from spring to autumn in crawl spaces. Therefore the concentration of mould spore is very high in most crawl spaces. Prefabricated bathrooms called "bath-units" are installed in most Japanese houses. The authors showed in the previous studies that there are infiltration routes between bath-units and walls that the routes may lead chemical compounds from crawl space to indoor space. In this study, the influence of mould infiltration from crawl space upon indoor mould concentration is investigated using a test house which consists of a lavatory and a bathroom. The structure of the house is wooden post-andbeam. The house is airtight and insulated according to the latest building code for save energy. The mould concentrations were measured in the crawl space and the indoor spaces continuously using a mould multi-sampling system with a pump, valves and impingers. Before the measurements, the indoor mould concentration was made low using an air cleaner. The air flow rates were measured using tracer gases. After the exhaust fan was switched on, the mould concentration increased. The number of infiltrated mould was calculated using air flow rates and mould concentrations. The results showed that mould infiltration ratio may be one of the important indicators of indoor air quality.
\end{abstract}

\section{Keywords}

Mould, Infiltration, Air Tightness, Crawl Space, Tracer Gas 


\section{Introduction}

One of factors to influence indoor mould concentrations is thought to be the infiltration of mould from the concealed spaces [1]-[3]. The authors made it clear in the previous studies that the infiltration from the concealed spaces-a crawl space, a beam space or an inside space of wall influences upon the indoor air quality as shown in Figure 1. And the consideration of this influence has been required in the amendment of building law since 2003 in Japan. Now house builders have to take into consideration the emission rates from the materials in the concealed spaces and the ventilation method. The authors continued to study on the characteristics of the infiltration using test houses and simulation programs [4] [5]. In most detached houses in Japan, a prefabricated bathroom made of plastic is installed. This prefabricated bathroom is built after the main structure: walls, roofs and windows.

The parts of the bathroom are packed and carried from a factory using a cart. And the bathroom is called bathunit. A unit is built inside the space of a bathroom. Therefore the unit has to be smaller than the space and this gap makes a concealed airflow route between the plastic wall of the bath-unit and the wall of the building structure. In common houses in Japan, some chemical compounds are used to prevent mites and the collusion of wooden structure. When a fan is used in the bathroom, these compounds infiltrate indoor spaces and the indoor air quality becomes worse. The indoor pressure is decompressed by many reasons: an exhaust ventilation system, indoor and outdoor temperatures difference, wind pressure, etc. In this way, large leaks around this type of bathroom may lead pollutants from the crawl space to the indoor spaces.

Figure 2 shows the infiltration of pollutants from crawl space to indoor space through the leakage around bath-unit. Nowadays the space under bath-unit is insulated and the airtight of the space has become higher. However, it is very difficult to be airtight around pipes and the edge of the floor, because those parts are hidden under the floor and the crawl space is too large to be airtight well. Therefore there is an air flow route from crawl space and the space under bath-unit. The pollutant will infiltrate from crawl space into the space under the bath-unit and go to the space above the bath-unit. And the pollutants will infiltrate to the beam space and then to indoor spaces through the air leaks on the interior surface such as windows, switch panels etc. In the bath-unit in common houses, an exhaust fan is installed. When these exhaust fans or the exhaust ventilation system is used, the infiltration rate will become higher. After the countermeasure toward the chemical pollution in 2003, the

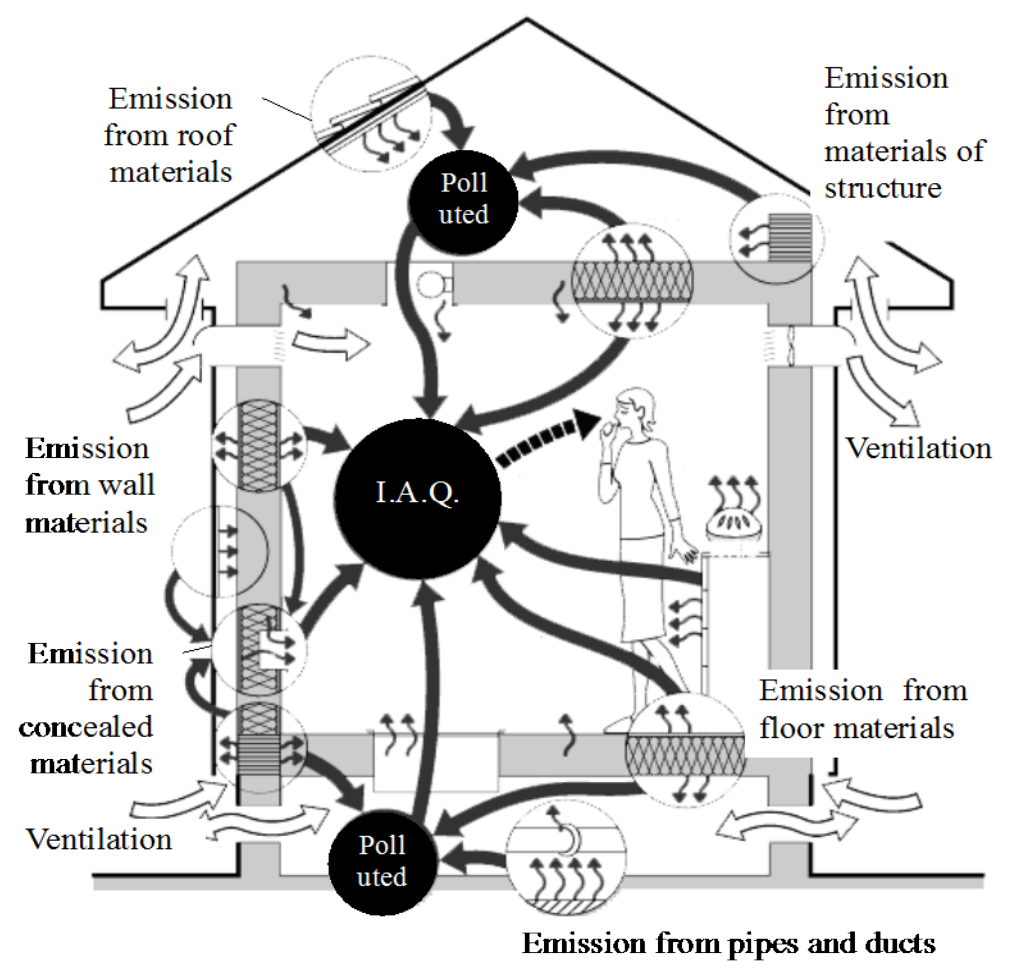

Figure 1. Influence of concealed pollution source up on I.A.Q. (indoor air quality). 


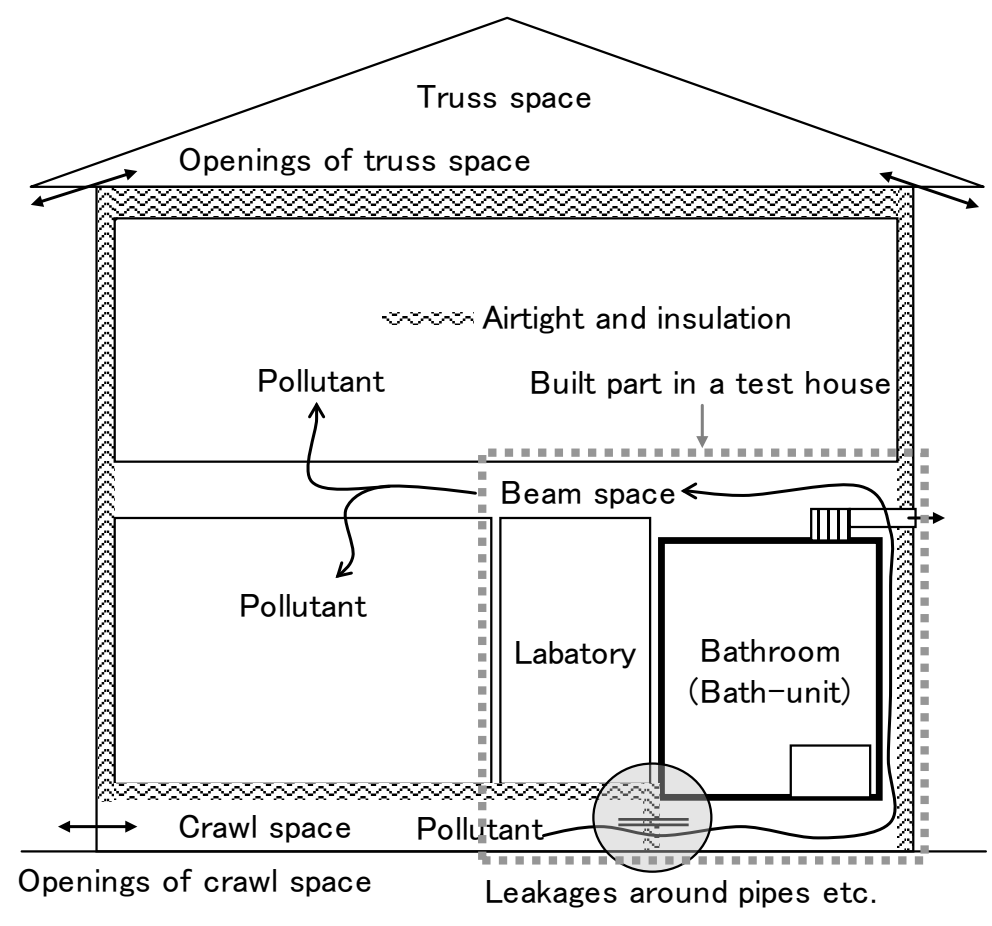

Figure 2. Infiltration of pollutant from crawl space to indoor space through the leakage around bath-unit and a part which built in a test house.

chemical compounds have been restricted. In the other hands, the mould growth in the humid crawl spaces was apprehended again [6] [7].

In this study, the influence of mould infiltration from crawl space upon indoor mould concentration is investigated using a test house constructed according to the latest building code. Airflow rates and mould concentrations were measured when the bath-room was decompressed in order to know the characteristics of mould infiltration from crawl space to indoor spaces.

\section{Methods}

\subsection{A Test House with Prefabricated Bathroom}

To measure the influence of concealed air leaks around bath-unit, a test house was built in Miyagigakuin Women's University as shown in Figure 3. A lavatory and a bathroom were built in the test house as shown in Figure 2. The leakage areas around the bath-unit were measured and the ventilation rates, the infiltration ratios from crawl spaces and the concentrations of pollutants were measured.

In the bath-unit, an exhaust fan is installed. Usually, the fan is operated when and after the bathroom is used in order to dry the bath room and prevent mould growth. In new houses, the whole house ventilation system is in-stalled and residents are instructed to use the system constantly for all seasons. In most new houses the exhaust ventilation system is installed and the indoor space is decompressed and the pressure difference is $-1 \mathrm{~Pa}$ to $-20 \mathrm{~Pa}$, corresponding to the airtight level of houses.

Figure 4 shows a measurement system of equivalent leakage areas of the concealed leakages and the leakages between the concealed spaces and indoor spaces, using airflow controllers, pressure analyzers, tracer gases and the monitors [8]. When the leakage areas between cell 1 and cell 2 are measured, cell 1 is made to be open to the outside and the air pressures of cell 3 and cell 4 are con-trolled to meet the pressure of cell 2 . Under this condition, the air of cell 2 goes only to cell 1 . The airflow rate from cell 2 to cell 1 accords with the airflow rate from outside to cell 2. The air flow rate can be known using the tracer gas method. The equivalent leakage areas were calculated with the measured pressure differences and measured air flow rates.

Figure 5 shows the equivalent leakage areas of the test house. The bath-unit was very airtight and the equivalent leakage could not be measured when the door was sealed. But the leakage area between the space under 

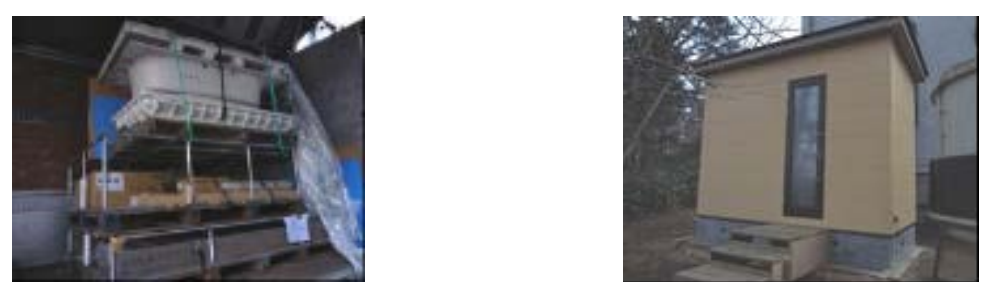

Figure 3. Packing of a bath-unit and a test house $(1.4 \mathrm{~m} \times 2.7 \mathrm{~m})$ with a bathunit.

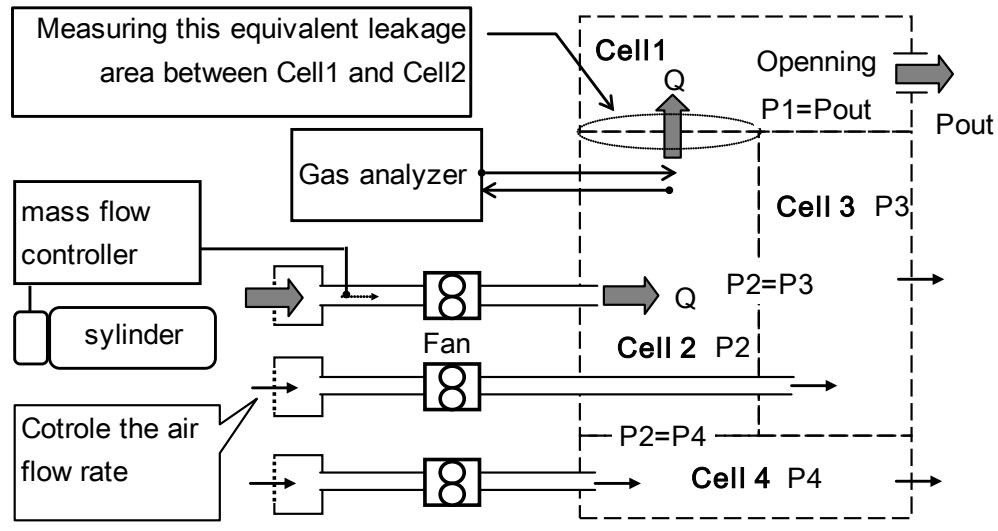

Figure 4. Measurement system of leakages around bath-unit.

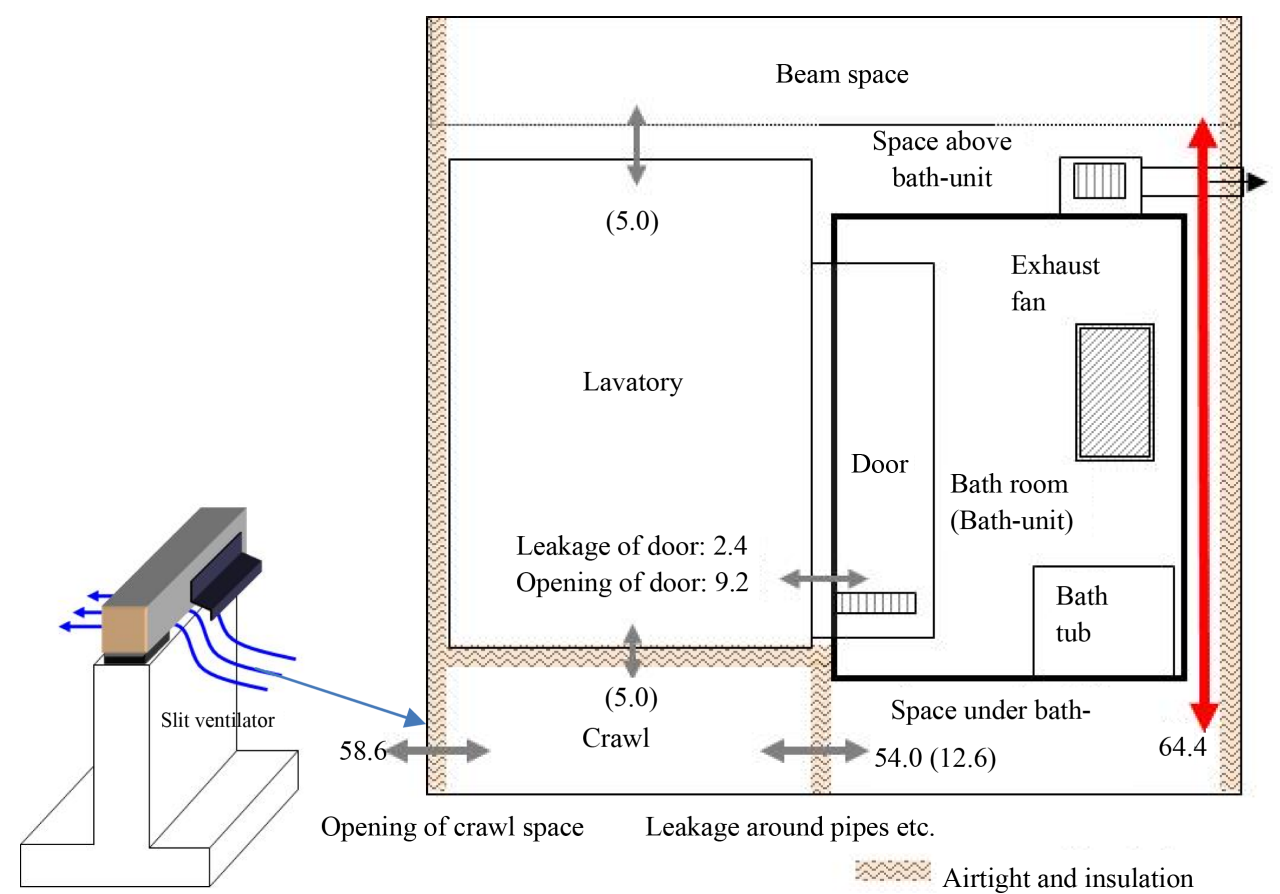

Figure 5. Equivalent leakage areas of the test house $\left(\mathrm{cm}^{2}\right)$.

bath-unit and the space above bath-unit was very large: $64.4 \mathrm{~cm}^{2}$. That between the space under bath-unit and the crawl space was also large: $54.0 \mathrm{~cm}^{2}$. After the first measurement, this part was improved to be airtight using tapes. The equivalent leakage area became $12.6 \mathrm{~cm}^{2}$. The equivalent leakage area of the opening between crawl space and outdoor space was not large, because a slit ventilator: Figure 5 is used in this house. This type of ventilator is used in most new houses in Japan. 


\subsection{Measurements of Airflow Rates and Infiltration Ratios}

The airflow rates and the infiltration ratios from the crawl space were measured using the tracer gas method as shown in Figure 6. R22 was released into the indoor space and SF6 was released into the crawl space and these concentrations were measured at the indoor space and the crawl space using multi gas monitor by INOVA. The air flow rates were calculated using the release rates of gases and these concentrations. The infiltration ratios were calculated as the ratios of the concentrations of SF6 to those of R22. This ratio shows the ratio of the infiltration rate of a pollutant to the generation rate of a pollutant in the crawl space. If the ratio is high, the in-door concentrations of pollutants from crawl space are considered to be high.

\subsection{Measurements of Mould Infiltration from Crawl Space}

Mould caught in the crawl space was cultivated in a laboratory, and then released to the crawl space as shown in Figure 7. The experiments were made in autumn when the ambient concentration of mould is not high. A medium with mould was installed in a chamber and the air is released to the crawl space from the chamber. The number of released mould is thought to be large immediately after the pump is switched on but the number decreases. These changes of released mould number depend on many factors: mould growth, temperature, humidity, etc. Therefore the prediction of the change is very difficult.

Figure 8 shows a continuous measurement system of mould concentrations which is produced in this study. The system can measure the concentrations in the concealed spaces: a crawl space and a wall cavity and the indoor space. The air was absorbed from these spaces in polytetrafluoroethylene tube in thirty minutes at the rate of $8 \mathrm{ml} / \mathrm{min}$. The mould was caught from the air by pure water in an impinger. The water with mould is diluted and applied to the media. In this study, the water was diluted in 1, 10, 100 times, and a potato dextrose agar medium was used. The retention rate of tube is $38 \%$ per its length $(1 \mathrm{~m})$ [8]. The length of tubes and the airflow rate were made the same values $(1.5 \mathrm{~m}, 8 \mathrm{ml} / \mathrm{min})$ at every sampling point. Therefore the collection efficiencies were thought to be the same value.

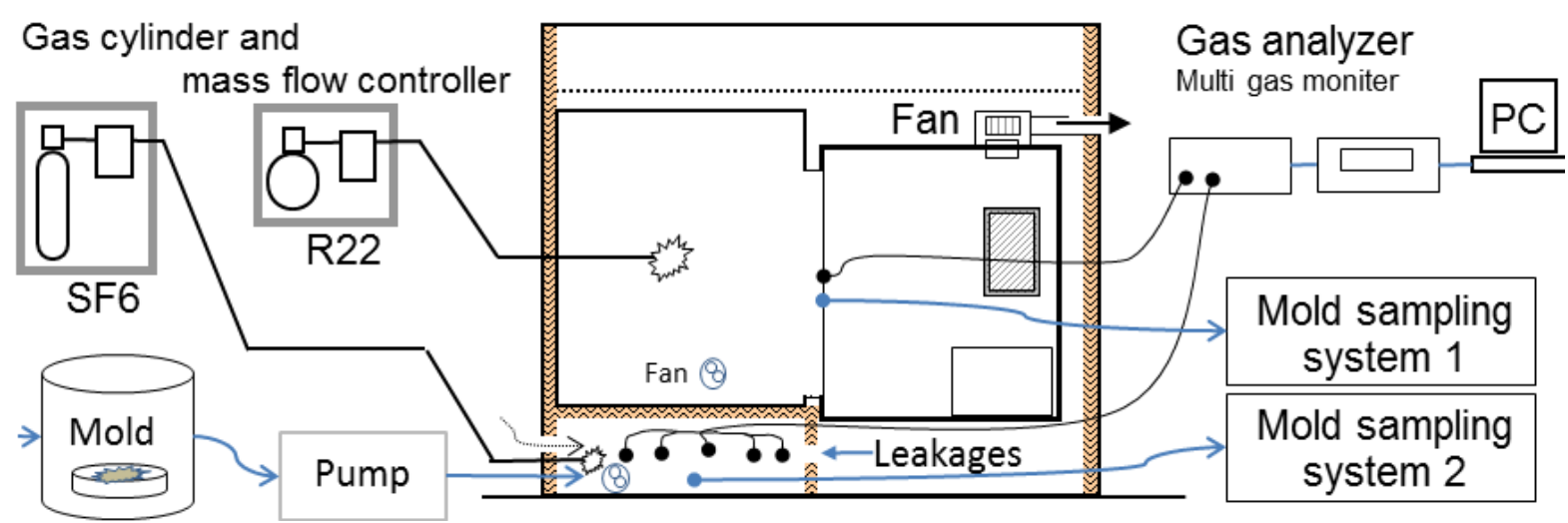

Figure 6. Measurement system of airflow rate and infiltration of mould.

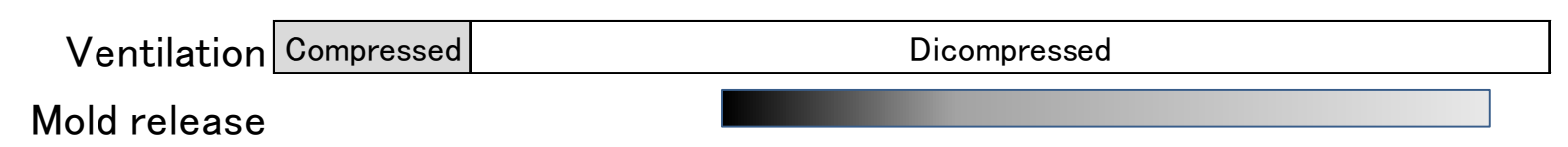

\section{Mold sampling}

CS:Crawl space

I S:Indoor space

\begin{tabular}{|c|c|c|c|}
\hline CS-1 & CS-2 & CS-3 & CS -4 \\
\hline IS-1 & IS-2 & IS-3 & IS-4 \\
\hline
\end{tabular}

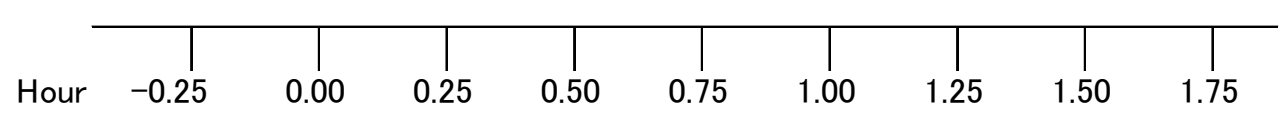

Figure 7. Time table of the experiment of the mould infiltration. 

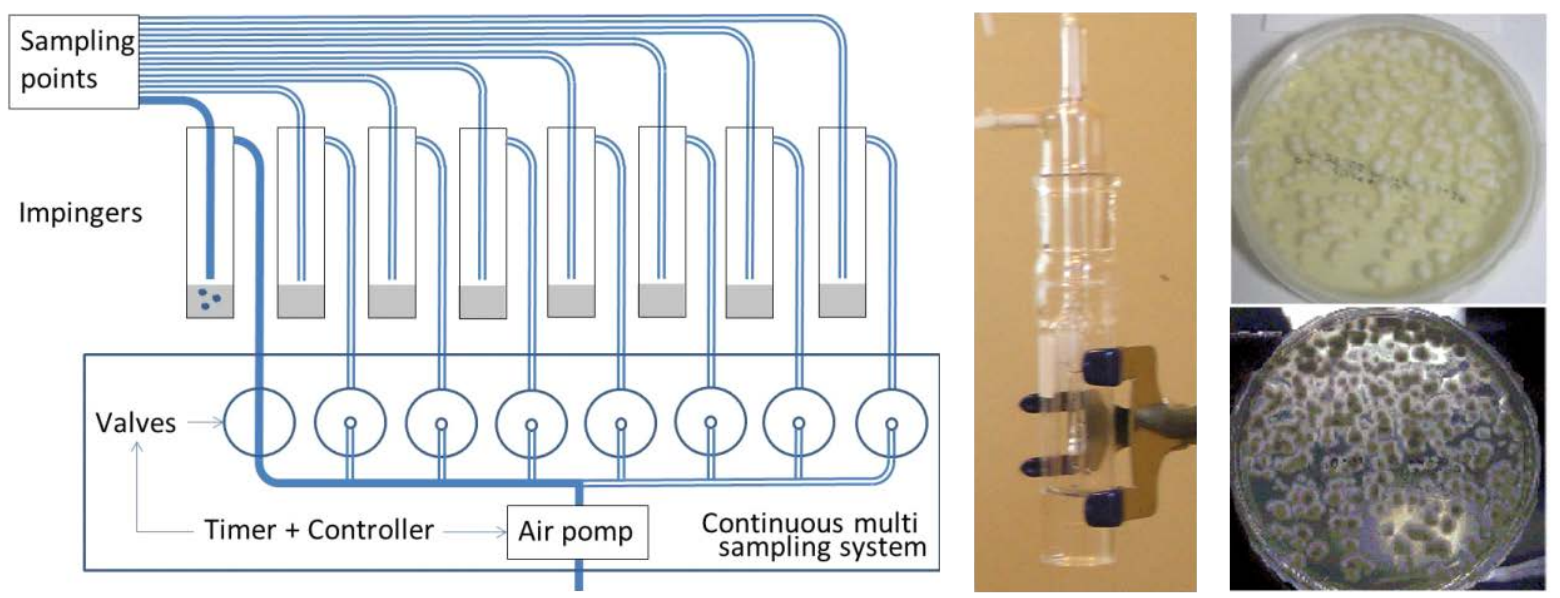

Figure 8. Continuous measurement system of mould concentrations. Continuous and multiple sampling system impinger P.D.A. medium.

\section{Results}

\subsection{Results of Airflow Rate and Infiltration Ratio from Crawl Space}

When the indoor space was decompressed, the pressure difference between the indoor space and the outside was 15.0 $\mathrm{Pa}$ and stable. The difference between the indoor space and the crawl space was $0.5 \mathrm{~Pa}$ and stable. The temperature difference between the indoor space and the outside was lower than 3.0 degree because the indoor space was not heated. Therefore the air flow velocities were thought to be stable.

Figure 9 shows the change of tracer gas concentrations. Concentrations change and become stable. The air flow rates are calculated from these stable concentrations, the space volumes, the release rates of tracer gases using equations on mass valances of tracer gases. The air is exhausted from bath room and the air is absorbed from the outdoor space and the crawl space. The air of crawl space goes to the inside space and the outside space. In this experiment, small fans were used in the crawl space to diffuse tracer gases well in the space. And the wind speed was low. Therefore the airflow rate from the crawl space to the outdoor space is thought to be stable. The infiltration ratio from crawl space was calculated from the stable indoor concentrations of R22 and SF6: IS-R22, CS-R22 in Figure 9. The ratio was 37.3\%. The result is lower than the former result [9] in the test house, because of the effect of a fan in the crawl space.

\subsection{Results of Mould Infiltration from Crawl Space}

Figure 10 shows the mould concentrations. In this experiment, aspergillus and penisillium were detected. The mould concentration of the crawl space was very high at the time of 0.5 hour and decreased rapidly. The concentration in the indoor space was high at the time of 0.5 hour. But the concentration decreased slowly in the indoor space. In the case of penisillium, the concentration increased and decreased. The change of concentration in the indoor space is thought to occur later than that in the crawl space.

Figure 11 shows the measured mould concentrations and the calculated concentrations. The change of released mould could not be measured but the characteristic of the change was able to be predicted using the next equation and the measured concentrations in the crawl space.

$$
\mathrm{R}_{\text {mould }}(\mathrm{t})=\mathrm{A} \cdot \mathrm{e}^{-\mathrm{bt}}
$$

where, $R_{\text {mould }}(t)$ is the mould release rate $(C F U / h)$. A is the mould release rate at the start time: $R_{\text {mould }}(0)$, $b$ is an index of decline. A and $\mathrm{b}$ are obtained from the calculated mould concentrations using the equation and the measured airflow rates to the measured mould concentrations of the crawl space.

CS-Total/calc. is the calculated concentration of the crawl space. The changes of concentration are similar to the measured concentration: CS-Total. Also in the case of penisillium, this relationship is recognized too.

IS-Total/calc. is the calculated concentration of the in-door space. The calculated concentration increased and 

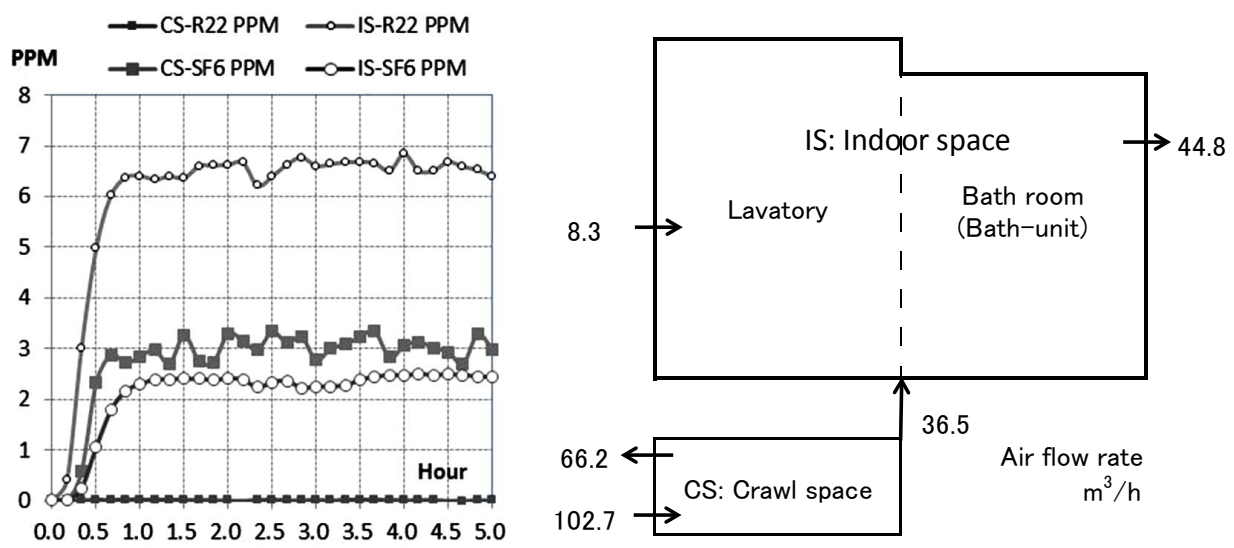

Figure 9. Concentrations of tracer gases and the measured airflow rate.
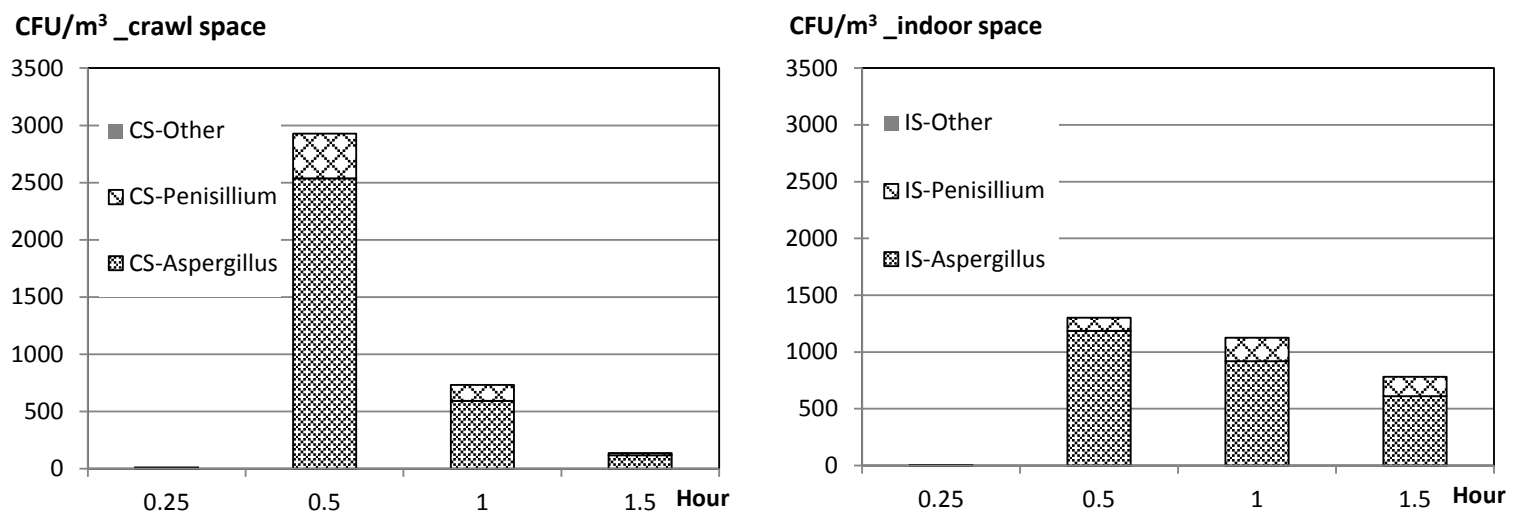

Figure 10. Measured mould concentrations in a crawl space and an indoor space.
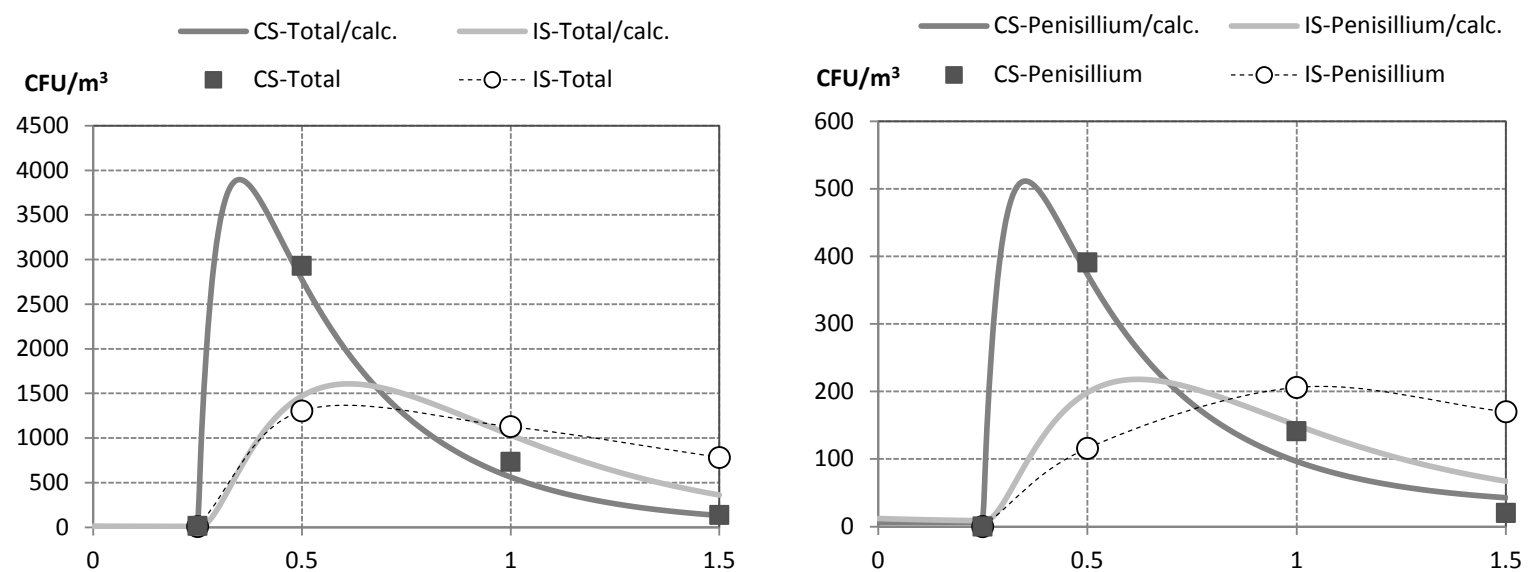

Figure 11. Measured mould concentrations and calculated concentrations from air flow rates.

decreased. The peak came later than the peak of the crawl space. The changes of calculated indoor concentration are similar to the measured indoor concentration: CS-Total. Also in the case of penisillium, this relation-ship is recognized.

The fact that the calculated indoor is similar to measured indoor concentration showed that the infiltration ratio of mould is close to the measured infiltration ratio using tracer gases: $37.3 \%$.

In the former studies, it was shown that volatile organic compounds move with tracer gases. In this study the 
results show that the mould moves with tracer gases too. The main airflow route from crawl space to indoor space in the test house is as follows. The air goes from the crawl space to space under bath-unit, and goes to space above bath-unit through the routes between the bath-unit and the wall, and goes to the indoor space through the gaps around the ceiling, the wall and the door between the bath-unit and the lavatory. Mould is thought to pass this route. And most moulds are thought to reach the indoor space from the crawl space. One of the reasons might be that the airflow rate is high in the routes.

\section{Conclusion}

The results of the experiments show that mould infiltrates from crawl space to indoor space through the routes around bathroom when the indoor space is decompressed by an exhaust fan. Mould moves like a tracer gas or V.O.C. These results show that the airtight space around the bathroom and the control of air quality in the crawl space are necessary. In the future study, the characteristics of mould movements have to be investigated also in real houses.

\section{Acknowledgements}

The study was a part of a national project "Development of Countermeasure Technology on Residential Indoor Air Quality" by National Institute for Land and Infra-structure Management under the Japanese government. The investigations were made with the cooperation of Center for Housing Renovation and Dispute Settlement Support.

The study was carried out by Grant-in-Aid Scientific Research of Japan Society for the Promotion of Science. The study was carried out with the cooperation of the students of universities which the authors belong to.

\section{References}

[1] Airaksinen, M., Pasanen, P., Kurnitski, J. and Seppänen, O. (2004) Microbial Contamination of Indoor Air Due to Leakages from Crawl Space: A Field Study. Indoor Air, 14, 55-64. http://dx.doi.org/10.1046/j.1600-0668.2003.00210.x

[2] Airaksinen, M., Kurnitski, J., Pasanen, P. and Seppänen, O. (2004) Fungal Spore Transport through a Building Structure. Indoor Air, 14, 92-104. http://dx.doi.org/10.1046/j.1600-0668.2003.00215.X

[3] Fazio, P., Bartlett, K., Yang, D.-Q., Rao, J.W. and Miao, G. (2005) Development of Experimental Procedure to Evaluate Potential Movement of Mould Spores from Wall Cavity to Indoor Environment. 10th Canadian Conference on Building Science and Technology, Ottawa, May 2005, 215-224.

[4] Hayashi, M., Osawa, H., Honma, Y. and Matsui, M. (2007) Prediction of Air Quality Considering the Concealed Air Leaks of Houses. Proceedings: Building Simulation 2007, 870-877. http://www.ibpsa.org/proceedings/BS2007/p208_final.pdf

[5] Hayashi, M. and Osawa, H. (2008) The Influence of the Concealed Pollution Sources upon the Indoor Air Quality in Houses. Building and Environment, 43, 329-336. http://dx.doi.org/10.1016/j.buildenv.2006.03.022

[6] Reponen, T., Willeke, K., Ulevicius, V., Reponen, A. and Grinshpun, S.A. (1996) Effect of Relative Humidity on the Aerodynamic Diameter and Respiratory Deposition of Fungal Spores. Atmospheric Environment, 30, 3967-3974. http://dx.doi.org/10.1016/1352-2310(96)00128-8

[7] Honma, Y., Enai, M., Fukushima, A. and Suzuki, H. (2002) The Influence of Airflow through Leakage around Floor on the Hygrothermal Conditions in a Crawl Space. The 6th Symposium on Building Physics in the Nordic Countries, Trondheim, 17-19 June 2002, 183-190.

[8] Yamada, H., Hayashi, M., Osawa, H., Hasegawa, K. and Honma, Y. (2013) Experiments on a Method to Measure Mold Concentration in a Wall Cavity Using a Teflon Tube. CLIMA2013, Article ID: 711.

[9] Hayashi, M. and Osawa, H. (2009) Influence of the Concealed Air Leaks upon the Indoor Air Quality in Houses with Prefabricated Bathroom. Proceeding of Room Vent 2009, 505-512. 
Scientific Research Publishing (SCIRP) is one of the largest Open Access journal publishers. It is currently publishing more than 200 open access, online, peer-reviewed journals covering a wide range of academic disciplines. SCIRP serves the worldwide academic communities and contributes to the progress and application of science with its publication.

Other selected journals from SCIRP are listed as below. Submit your manuscript to us via either submit@scirp.org or Online Submission Portal.
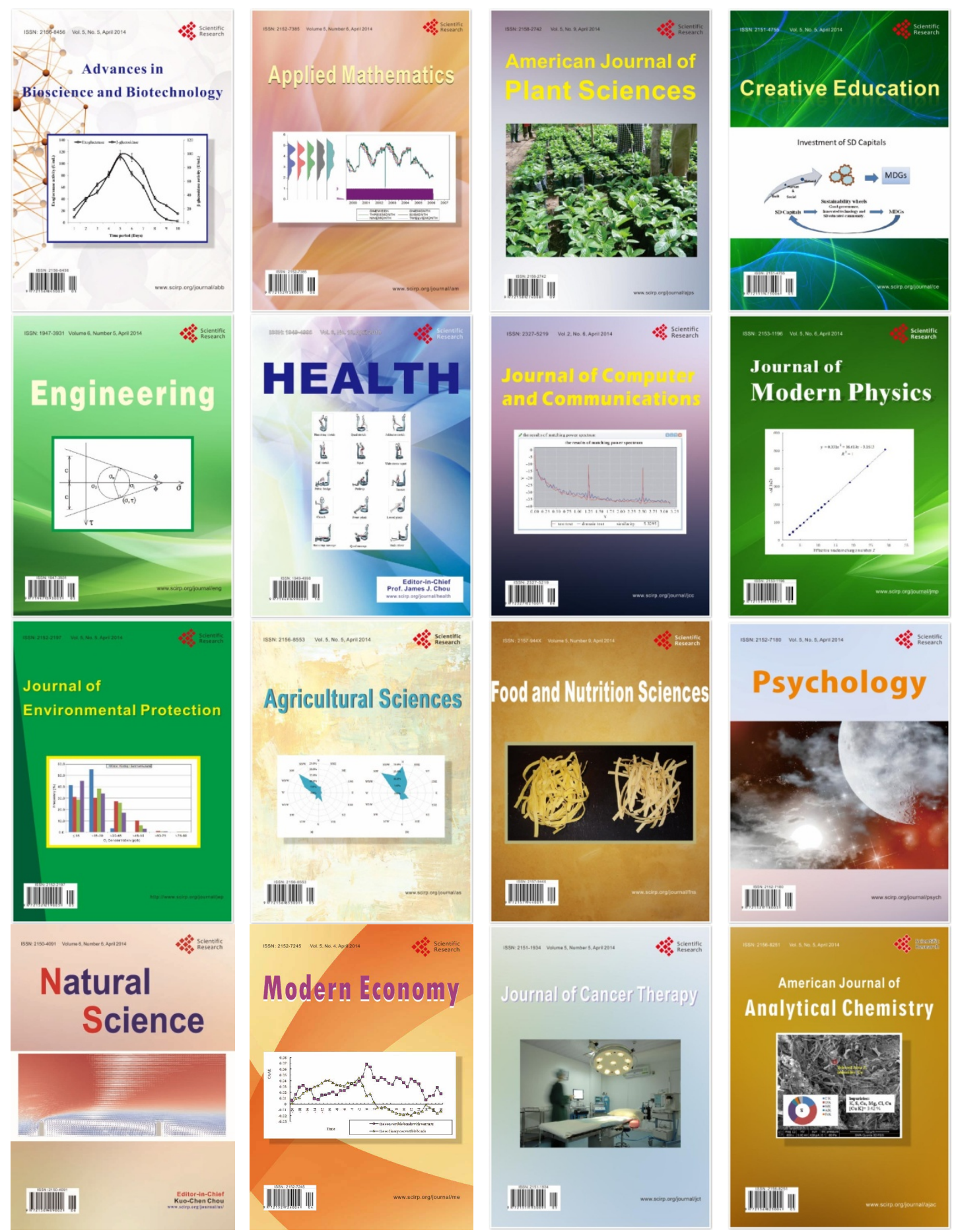